\title{
Vuorovaikutus myötätuulessa
}

Ilmapiiri yhteiskunnassamme on nykyään viestintämyönteinen. Erityisesti ihmisten välistä vuorovaikutusta arvostetaan vahvasti. Hyvän vuorovaikutuksen merkitystä korostetaan sekä yksityisen elämän että työpaikan kaikenlaisissa tilanteissa. Jokaisen onkin helppo ymmärtää rakentavan keskustelun voima perheessä tai tuloksellisen tiimiviestinnän tai sujuvan tiedonkulun ratkaiseva rooli työssä. Vuorovaikutuksella on nyt myönteinen kaiku - se on arvo sinänsä. Vuorovaikutuksen tutkijoiden ei myöskään tarvitse perustella työnsä tärkeyttä.

Kansainvälinen Taloudellisen yhteistyön ja kehityksen yhteistyöjärjestö OECD on määritellyt lähivuosikymmeninä tarvittavaa avainosaamista muun muassa "neljän c:n" avulla. Nämä ovat creativity, critical thinking, communication ja collaboration. Luovuuden, kriittisen ajattelun, viestinnän ja yhteistyön taidot ovat keskeistä osaamista 21 . vuosisadan monimuotoisessa, vielä nyt tuntemattomia haasteita tuovassa työelämässä. Tulevaisuuden taidoiksi mainitaan usein myös konfliktinhallinta ja ongelmanratkaisu sekä ryhmä- ja tiimityö, jotka nekin ovat geneeristä, asiantuntijatyössä laajasti sovellettavaa osaamista.

Suomessakin opetus- ja kulttuuriministeriön kannanottojen mukaan sosiaalisten taitojen kehittämisen tulisi sisältyä kaikkeen koulutukseen, päiväkodista tohtorikoulutukseen saakka. Viestintä- ja vuorovaikutusosaamista ei harjoitella vain lapsuudessa ja nuoruudessa, vaan uutta opittavaa tulee elämässä myöhemminkin kaiken aikaa.

Valtioneuvosto valmistelee parhaillaan tulevaisuusselontekoaan, joka annetaan eduskunnalle syksyllä 2013. Valtioneuvosto haluaa tunnistaa kehityssuuntia, joita Suomen kannattaisi noudattaa, kun se tavoittelee hyvää tulevaisuutta. Katse ulottuu muutaman vuosikymmenen päähän: selonteon teemana on "Suomen kestävä kasvu ja kansalaisten hyvinvointi vuonna 2030". Selonteon ennakointiprosessin useissa ideointi- ja keskustelutilaisuuksissa on käsitelty tulevaisuuden osaamista ja sen edellyttämää koulutusta. Tulevan työelämän osaamistarpeita on luonnehdittu monilla puheviestinnästä tutuilla käsitteillä: vuorovaikutus, yhteistyö, tiimityö, yhteisöllisyys, verkostoituminen, monikulttuurisuus sekä viestintäteknologian vuorovaikutuskäytön kehittäminen.

Vuorovaikutuksen kysymykset kiinnostavat nykyään usean alan toimijoita. Tuntuu siltä, että ihmisten välisen kanssakäymisen ja yhteistyön merkitys aletaan vasta nyt ymmärtää toden teolla. Niinpä vuorovaikutuksen saloja selvitetään innokkaasti monissa käytäntölähtöisissäkin tutkimushankkeissa. Työelämä tarjoaa runsaasti aineksia ja aineistoa käytännön projekteihin, joissa halutaan kartoittaa työpaikan vuorovaikutussuhteiden solmuja tai ratkoa työyhteisön viestintäongelmia. Selvityksissä ei kuitenkaan päästä pintaa syvemmälle ilman 
vuorovaikutuksen teoriaperustan ja aikaisemman tutkimustiedon tuntemista ja ymmärtämistä sekä vuorovaikutuksen analysointiosaamista. Tarkastelu jää väkisinkin tapaus- ja tilannekohtaiseksi, eikä se tuota pysyviä eväitä viestinnän todelliseksi parantamiseksi.

Puheviestinnän tutkijalla on usein myös sellainen olo, että vuorovaikutuksen pyörä keksitään muilla tieteenaloilla uudestaan. Otan kaksi esimerkkiä.

Organisaatioviestinnässä työntekijöiden välinen vuorovaikutus on vasta viime aikoina ymmärretty olennaiseksi osaksi työyhteisön viestintää. Näihin päiviin asti on organisaatioviestinnän kirjallisuudessa tehty ero "virallisen" ja "epävirallisen" viestinnän kesken: virallinen on tarkoittanut esimerkiksi johdon ja tiedottajan tiedonantoja työntekijöille ja epävirallinen työntekijöiden keskinäistä vuorovaikutusta. Epävirallisen viestinnän osalta on puhuttu jopa "puskaradiosta", jonka on nähty haittaavan virallista viestintää. Nyt on kuitenkin oivallettu, että työtovereiden ja kollegoiden viestintä työpaikalla - "horisontaalinen" viestintä - on tärkeä voimavara koko organisaatiolle. Se on identifoitumisen ilmentymä, sitoutumisen väline ja olennainen osa työntekoa. Se on kasvokkaista tai teknologiavälitteistä vuorovaikutusta organisaatiossa, yhtä keskeistä kuin johtoryhmän palaveri, henkilökuntakokous tai johtajan ja alaisen välinen vuorovaikutus.

Toisen esimerkin tarjoaakin johtamisen tutkimus. Siinä painotetaan nykyään dialogisen johtamisen periaatteita. Johtaminen on suurelta osin vuorovaikutusta, ja johtajalta edellytetään vuorovaikutusosaamista. Dialogisen johtamisen tulisi toteutua henkilökunnan kanssa käydyissä keskusteluissa sekä johtajan ja alaisen välisessä vuorovaikutussuhteessa. Näissä luodaan yhteisiä merkityksiä sekä rakennetaan, muokataan ja uudistetaan yhteistä todellisuutta. Johtamista tutkivissa tieteissäkin on siis otettu käyttöön merkitysten yhteensovittamisen teorian ja symbolisen interaktionismin teorian perusperiaatteet, jotka ovat puheviestinnän tutkijoille ja muille asiantuntijoille perin tutut.

Meillä vuorovaikutuksen tutkijoilla on viisasten kivi hallussamme: me osaamme orientoitua 21. vuosisadan työelämän ja sen tutkimisen haasteisiin. Me tiedämme, millaisia elementtejä ihmisten ja yhteisöjen vuorovaikutusmaailmaan sisältyy. Meillä on työkalut vuorovaikutussuhteen ja -tilanteen analysointiin. Me tunnistamme viestinnän prosessit ja rakenteet, olipa kyseessä kahdenvälinen kohtaaminen, ryhmäviestintätilanne, virtuaalitiimi taikka yhteisön tai verkoston sisäiset suhteet. Meillä on tieto siitä, miten työyhteisö muodostuu ja kehittyy työntekijöiden välisten viestintäsuhteiden varassa ja mitkä elementit puolestaan tekevät johtamisesta "dialogista".

Vuorovaikutuksen tutkijoita tarvitaankin tieteidenvälisessä yhteistyössä. Aivan kuten Suomen Akatemian laatima Tieteen tila 2012 -raportti ja sen viestintätieteiden osuus kehottavat, meidän kannattaa hakeutua kumppaneiksi muiden tieteenalojen edustajien kanssa. Puheviestinnän kysymyksenasettelut ovat useasti yhdistettävissä sekä muiden tieteenalojen intresseihin että käytännön 
viestintäkontekstien tarpeisiin. Puheviestintä on hyvä kumppani monitieteisissä tutkimushankkeissa.

Tämän kahdeksannen Prologi-vuosikirjan artikkelipyynnössä halusimme tuoda esiin sen, että puheviestinnän vuosikirja tarjoaa monitieteisen foorumin useiden tieteenalojen vuorovaikutustutkimukselle. Toivoimme muillakin tieteenaloilla työskentelevien kiinnostuvan tarjoamaan artikkeleitaan. Vielä toiveemme ei täysin toteutunut. Saimme kyllä tarjouksia, mutta abstraktien tai käsikirjoitusten fokus ei ollut vuorovaikutuksessa. Prologin tulevaisuus ei kuitenkaan voi rakentua pienehkön puheviestintä-tieteenalan varaan. Vuosikirjan kehittäminen vuorovaikutuksesta kiinnostuneiden tutkijoiden keskeiseksi kotimaiseksi julkaisufoorumiksi on seuraavien toimituskuntien haaste.

Toimituskunta sai tähän Prologiin artikkeliehdotuksiksi yhdeksän abstraktia. Niistä kelpuutimme neljä. Näiden hyväksyttyjen abstraktien pohjalta saimme artikkelikäsikirjoitukset. Vertaisarvioijat hyväksyivät niistä kaksi. Toimituskunta edellytti, että kirjoittajat ottavat käsikirjoituksia työstäessään huomioon referee-lausunnoissa saamansa parannusehdotukset. Toimituskunta hyväksyi molemmat työstetyt artikkelit vuosikirjaan.

Lisäksi tässä Prologissa julkaistaan neljä lectio praecursoriaa. Ne ovat niiltä neljältä tohtorilta, jotka ovat valmistuneet edellisen Prologi-vuosikirjan julkaisemisen jälkeen. Yksi lektioista oli alunperin englanninkielinen, mutta se on vuosikirjaa varten kirjoitettu uudestaan suomeksi.

Tässä vuosikirjassa julkistetaan toimituskunnan kutsumat vertaisarvioijat kuluneen kahden vuoden ajalta. Esitän kaikille arvioijille mitä parhaimmat kiitokseni arvokkaasta toiminnasta puheviestinnän vuosikirjan Prologin hyväksi. Ilman heidän panostaan emme voisi huolehtia vuosikirjamme laadusta.

Toimituskuntamme on työskennellyt kahden vuoden ajan iloisena saamastaan tärkeästä tehtävästä. Nyt toisen vuoden päättyessä kiitän lämpimästi toimituskunnan jäseniä Anu Sivusta, Leena Mikkolaa ja Vilja Laaksosta mitä asiantuntevimmasta ja sujuvimmasta yhteistyöstä. Erityislämpimät kiitokset toimitussihteerille Vilja Laaksoselle, jonka järjestelmällinen ja aina yhtä hyväntuulinen panos Prologin hyväksi on ollut korvaamaton.

\section{Jyväskylässä marraskuussa 2012 \\ Maarit Valo, päätoimittaja}

